\title{
Some Biofertilizers Relieved the Stressful Drawbacks of Calcareous Soil upon Black Seed (Nigella sativa L.) Through Inhibiting Stress Markers and Antioxidant Enzymes with Enhancing Plant Growth
}

\author{
Manal El-Zohri $^{1 *}$, Noha Medhat ${ }^{2}$, Full-Elnada M. Saleh ${ }^{2}$ \\ and S.S.M. El-Maraghy ${ }^{1}$ \\ Department of Botany and Microbiology, Faculty of Science, \\ Assiut University, Assiut 71516 and ${ }^{2}$ Medicinal and Aromatic \\ Plants Research Department, Horticulture Research \\ Institute, Agricultural Research Center, Cairo, Egypt
}

\begin{abstract}
ALCAREOUS soils have stressful properties to plant growth; they represent about $25-30 \%$ of the Egyptian total area. To improve soil characteristics and hence plant growth, a number of biofertilizers (diatomaceous earth, Nostoc, sewage effluent and yeast) in addition to Hoagland medium were applied at successively increasing concentrations. The growth of Nigella sativa (black seed), a folk medicinal plant famous for its oils, was enhanced by all the applied treatments. Enhancement in plant biomass showed highest levels at a certain concentration of each treatment; sewage $(20 \%)$ followed by diatomaceous earth $(6 \mathrm{~g} / 5 \mathrm{Kg})$, Nostoc $(1 \mathrm{mg} / 5$ $\mathrm{Kg})$, yeast $\left(4 * 10^{12}\right.$ cell/L) and Hoagland $(1 / 4 \mathrm{x})$. The applied treatments variably altered carbohydrates, proteins and amino acid proportions in plant biomass. Stress marker (malondialdehyde and proline) contents and antioxidant enzymes activity (superoxide oxidase, catalase and ascorbate peroxidase) have been all significantly reduced in shoots and roots of the treated plants, compared with those of the control plants grown on calcareous soil alone. Subsequently, it could be inferred that calcareous soil triggered oxidative stress and the applied biofertilizers extinguished it and overcame the stressful drawbacks of calcareous soil in terms of enhanced plant growth. Energy and carbon skeletons that are usually leaked into defense molecules (MDA, proline and antioxidant enzymes), have been saved for growth upon amendment of the stressful calcareous soil.
\end{abstract}

Keywords: Nigella sativa, Diatomaceous Earth, Sewage Effluent, Nostoc, Yeast.

Soils with high $\mathrm{CaCO}_{3}$ belong to the calcisols and related calcic subgroups of other soils and are generally of low organic matter content and lack nitrogen. Calcareous soils have more than $15 \% \mathrm{CaCO}_{3}$ that may occur in various forms

*Corresponding author: mnzohri@yahoo.com 
including, powdery, nodules, crusts, etc. (FAO, 2014). Calcareous soils occur naturally in arid and semi-arid regions because of relativity little leaching. They also occur in humid and semi arid zones if their parent material is rich in $\mathrm{CaCO}_{3}$, such as lime stone, shells and the parent material is relativity young and has undergone weathering (Brody and Weil, 1999). Calcareous soils cover more than $30 \%$ of the earth surface and their $\mathrm{CaCO}_{3}$ content varies from a few percent to $95 \%$ (Marschner, 1995).

In Egypt, the calcareous soils constitute about $25-30 \%$ of the total area (Abu-Elela, 2002). Elgabaly et al. (1969) reported that in the Arab Republic of Egypt, the range of $\mathrm{CaCO}_{3}$ content in the alluvial soils of the Nile Valley and Delta varies from 1 to 3 percent. Soils with medium to high $\mathrm{CaCO}_{3}$ content $(3$ to 30 percent) border the fringe zone of the Nile Valley. Beyond the fringe zone of the Nile Valley and Delta, the $\mathrm{CaCO}_{3}$ contents in soils of the eastern and western desert zones increase to a range of 30 to 80 percent and higher. The calcareous soil areas that are being reclaimed as a result of the construction of the High Dam in Egypt is estimated by 300000 feddans, most of which lie west of the Nile Delta where the mean annual rainfall is 110 mm/year (Kadry, 1973). The $\mathrm{CaCO}_{3}$ content of the soils in this area ranges between 20 to 43 percent, the origin of which is the sedimentary parent material. Usually, two approaches; chemical and biological, are used to define calcareous soils. Loeppert and Suarez (1996) defined them as those soils containing amounts of calcium carbonate to affect distinctly the soil properties related to plant growth. These properties could be physical, such as the soilwater relations and crusting, or chemical such as the availability of plant nutrients.

According to Kadry (1973), the most fastidious problems, which need specific treatments and special precautions and management techniques, for profitable utilization of calcareous soils in agriculture, are: their poor physical characteristics and associated poor water retention; the low contents of available essential nutrients and the rapid fixation of applied nutrients if added to the soil. Three approaches are often applied for improving calcareous soil; physico-chemical characteristics for growth and productivity of planted crops. These approaches include the application of organic materials; the supplementation and management of essential nutrients in addition to the application of biofertilizers (Roig et al., 2012 and Hernández et al., 2014).

Biofertilizers are low-price biopreparation that contain one or more type of living beneficial microbes capable of improving plant growth and increasing the yield and quality of cultivated crops by increasing the availability and uptake of some essential nutrients in the inadequate soil (Pereira and Castro, 2014). In addition, biofertilizers could help in the production of auxins and hormonal substances that enhance root and shoot growth and development (Abdel-Aziez et al., 2014). Plant protection against soil borne pathogens by produced antibiotics is another benefit for using biofertilizers to increase the productivity of calcareous soils (El-Tarabily and Sivasithamparam, 2006).

Egypt. J. Bot. 57, No.1 (2017) 
Nigella (Nigella sativa L.) is an annual herbaceous plant belonging to family Ranunculaceae (Al-Gaby, 1998) growing in countries bordering the Mediterranean region (including Egypt) and in Western Asian countries including, India, Pakistan, Afghanistan and Saudi Arabia (Subhash et al., 2008). Seeds of Nigella sativa taste slightly bitter and peppery with a crunchy texture. They are known in Arabic as 'Al-Habba Al-Sawdaa' or 'Al-Kammoon Al-Aswad' (Al-Gaby, 1998) and 'Habbet el Baraka' and 'Shunez' (Burits and Bucar, 2000). Nigella sativa seeds represent the useful product used for edible and therapeutic purposes in many countries (Al-Naggar et al., 2003). Nigella seed oil or extract also has protective and curative actions (Gilani et al., 2004).

This study has been planned to enhance the growth of this medicinal plant (Nigella sativa) in calcareous soil, which extends to about $25 \%$ of the Egyptian soil by adding different biofertilizers and studying some growth parameters and antioxidant apparatus.

\section{Materials and Methods}

This study was conducted in the Faculty of Science greenhouse, Assiut University during 2012/ 2013 using Nigella sativa grown in calcareous soil supplied by the research station of Arab El-Awamer, Assiut. Seeds used in the experiments were obtained from Arab EL-Awamer research station, Agriculture Research Center (A.R.C), Assiut Governorate.

A pot experiment was carried out in open air under natural conditions during winter season from the first of November (minimum/maximum temperature was around $15 / 30^{\circ}$ C) to the beginning of May (minimum/maximum temperature was around $21 / 38^{\circ} \mathrm{C}$ ).

Fifteen seeds were sown per pot, containing $5 \mathrm{Kg}$ calcareous soil in three replicates. All pots were irrigated with equal amounts of tap water for one month using $90 \%$ field capacity. After thinning, ten uniform seedlings were allowed to continue for one month in each pot, and then the treatments under study were applied and then the plants were further grown for two months up to the seed harvest. Four different biofertilizers in addition to Hoagland medium (Hoagland and Arnon, 1950) were added to treat calcareous soil as follows:

1- Diatomaceous earth obtained from Growth Promoters World for trading, import and supplies, applied at concentrations of $1.5,3,6,12,24 \mathrm{~g} / 5 \mathrm{Kg}$.

2- Sewage effluent brought from Alarbaeen sewage treatment station (Assiut city) applied at concentrations of $20 \%, 40 \%, 60 \%, 80 \%$ and $100 \%$.

3- Nostoc, grown in Botany and Microbiology Department, Faculty of Science, Assiut University, applied at concentrations of 1, 2, 3, 4 and 5 $\mathrm{mg} / \mathrm{Kg}$. 
4- Liquid yeast-Plus, $10^{12}$ cells $/ \mathrm{ml}$, supplied by the Unit of biofertilizers, Faculty of Agriculture, Ein Shams University, applied at concentrations of $4 * 10^{12}, 8 * 10^{12}, 16 * 10^{12}, 32 * 10^{12}$ and $64 * 10^{12}$ cell/L.

5- Modified Hoagland solution, applied at concentrations of 1/10, 1/8, 1/6, 1/4 and $1 / 2 x$.

6- Control and treated plants received only tap water twice a week, except Hoagland treated plants .

Harvesting and plant analysis

At the end of the experimental period, plants were sectioned into roots and shoots. The roots were only briefly rinsed with deionized water and blotted gently with filter paper. The shoots and roots were quickly weighed for fresh weight $(\mathrm{FW})$ determination, immediately frozen in liquid nitrogen and stored at $-80^{\circ} \mathrm{C}$ for further analysis. Another fraction of freshly harvested roots and shoots were oven-dried at $70^{\circ} \mathrm{C}$ for 48 hour (until constant weights) in order to determine the dry weight (DW). Water use efficiency (WUE) was calculated as $\mathrm{mg}$ DW/g water; irrigation water was calculated throughout the cultivation period of three months.

\section{Analytical methods}

The photosynthetic pigments (chlorophyll $\mathrm{a}$, chlorophyll $\mathrm{b}$ and carotenoids) were estimated at $60{ }^{\circ} \mathrm{C}$ in ethanolic extracts according to Lichtenthaler (1987). Soluble proteins content was determined in the plant extract using Folin reagent according to Lowry et al. (1951). The anthrone sulphuric acid method (Schlegel, 1956) was used for carbohydrate determination. Free amino acids were determined according to the method of Moore and Stein (1948) in the same water extract of proteins and carbohydrates. Proline was determined as described by Bates et al. (1973).

\section{Determination of membrane damage}

Lipid peroxidation in root samples was determined by measuring the amount of malondialdhyde (MDA) produced by the thiobarbituric acid (TBA) reaction as described by Heath and Packer (1968). The MDA concentration was calculated by its molar extinction coefficient $\left(155 \mathrm{mM}^{-1} \mathrm{~cm}^{-1}\right)$ and the results were expressed as $\mu \mathrm{M} \mathrm{MDA} / \mathrm{g}$ DW.

Preparation of enzyme extract and assay of enzyme activity

Shoot and root tissues $(0.5 \mathrm{~g})$ were ground to a fine powder in liquid $\mathrm{N}_{2}$ and then homogenized in $5 \mathrm{ml}$ of $100 \mathrm{mM}$ potassium phosphate buffer ( $\mathrm{pH} 7.8$ ) containing $0.1 \mathrm{mM}$ ethylenediamine tetraacetic acid (EDTA) and $0.1 \mathrm{~g}$ polyvinylpyrrolidone (PVP). The homogenate was centrifuged at 10000xg for $10 \mathrm{~min}$ at $4^{\circ} \mathrm{C}$ and the supernatants were collected and used for the assays of catalase, ascorbate peroxidase, and superoxide dismutase. All colorimetric measurements (including enzyme activities) were made at $20^{\circ} \mathrm{C}$ using a Unico UV-2100 spectrophotometer. 
Superoxide dismutase (SOD, EC 1.15.1.1) activity was assayed by following the autoxidation of epinephrine (adenochrome) as described by Misra and Fridovich (1972), but with some modifications the extinction coefficient was $2.5 \mathrm{mM}^{-1} \mathrm{~cm}^{-1}$. Catalase (CAT, EC 1.11.1.6) activity was determined by following the consumption of $\mathrm{H}_{2} \mathrm{O}_{2}$ for one min (Aebi, 1984); the extinction coefficient is $43.6 \mathrm{M}$. Ascorbate peroxidase (APX, EC 1.11.1.11) activity was determined according to the method described by Nakano and Asada (1981), but with some modifications.

\section{Statistical analyses}

All data obtained was subjected to a one-way analysis of variance (ANOVA), using the SPSS statistical package. For comparison of the means, Duncan's multiple range tests $(\mathrm{p}<0.05)$ were used.

\section{Results}

As shown in the materials and methods, four biofertilizers (diatomaceous earth, sewage effluent, yeast, or Nostoc) in addition to Hoagland medium were used for calcareous soil amendment. Each, in five, successively increasing concentrations, improved the growth of Nigella sativa (black seed) in terms of fresh weight and dry mass of plants. Although all concentrations of all the studied treatments were stimulatory to plant growth, only the concentration of each treatment that induced the highest plant growth (fresh weight and dry mass), is presented in this work to conserve space. These concentrations are 6 $\mathrm{g} / 5 \mathrm{Kg}$ diatomaceous earth, $20 \%$ sewage effluent, $1 \mathrm{mg} / \mathrm{L}$ Nostoc, $4 * 10^{12}$ cell/L yeast and 1/4x Hoagland medium.

\section{Fresh biomass}

The effect of the selected concentrations on shoot fresh weight was stimulatory but variable as shown in figure 1 . The maximum induction in shoot fresh weight was about $65 \%$ higher than the control, induced by $1 \mathrm{mg} / \mathrm{Kg}$ Nostoc followed by $20 \%$ sewage that increased shoot fresh weight to $34 \%$ higher than the control. Yeast $\left(4 * 10^{12}\right.$ cell/L) and Hoagland $(1 / 4 \mathrm{x})$ treatments recorded comparable induction values of about $26 \%$ higher than the control while shoot fresh weight was only induced up to $12 \%$ higher than the control by $6 \mathrm{~g} / 5 \mathrm{Kg}$ Diatomaceous earth (Fig. 1).

The highest stimulatory effect in root fresh weight was $135 \%$ higher than the control, induced by $20 \%$ sewage, followed by $105 \%$ higher than control as recorded by $6 \mathrm{~g} / 5 \mathrm{Kg}$ diatoms. Hoagland solution $(1 / 4 \mathrm{x})$ and $4 * 10^{12}$ cell/L yeast recorded comparable stimulation values of about $25 \%$ higher than the control. However, $1 \mathrm{mg} / \mathrm{L}$ Nostoc did not show significant induction for root fresh weight (Fig. 1).

\section{Dry biomass}

Figure 1 shows the stimulatory effect of the selected concentrations on shoot dry weight. The highest Nigella sativa shoot dry weight (about 59\% 
higher control) was recorded by $20 \%$ sewage and $1 \mathrm{mg} / \mathrm{L}$ Nostoc. Hoagland medium $(1 / 4 \mathrm{x}), 4 * 10^{12}$ cell/L yeast and $6 \mathrm{~g} / 5 \mathrm{Kg}$ diatoms significantly stimulated shoot dry weight by about $42 \%, 31 \%$ and $26 \%$ higher than the control, respectively.

Root dry weight of the tested plant exhibited about $312 \%$ enhancement on treatment with sewage water $(20 \%)$ in relation to the control plants (Fig. 1). Diatomaceous earth $(6 \mathrm{~g} / 5 \mathrm{Kg})$ induced the following maximum induction of root dry mass (about $250 \%$ in relation to the control). Negligible stimulation in root dry weight accompanied Nostoc, yeast and Hoagland treatments.

Water use efficiency (WUE), as mg dry mass per $\mathrm{g}$ water supplemented for a plant, exhibited significant rise at all treatments, as compared to the control (Fig. 1) in the following order: sewage effluent $>$ Nostoc $>$ Hoagland solution $>$ diatomaceous earth $>$ yeast.
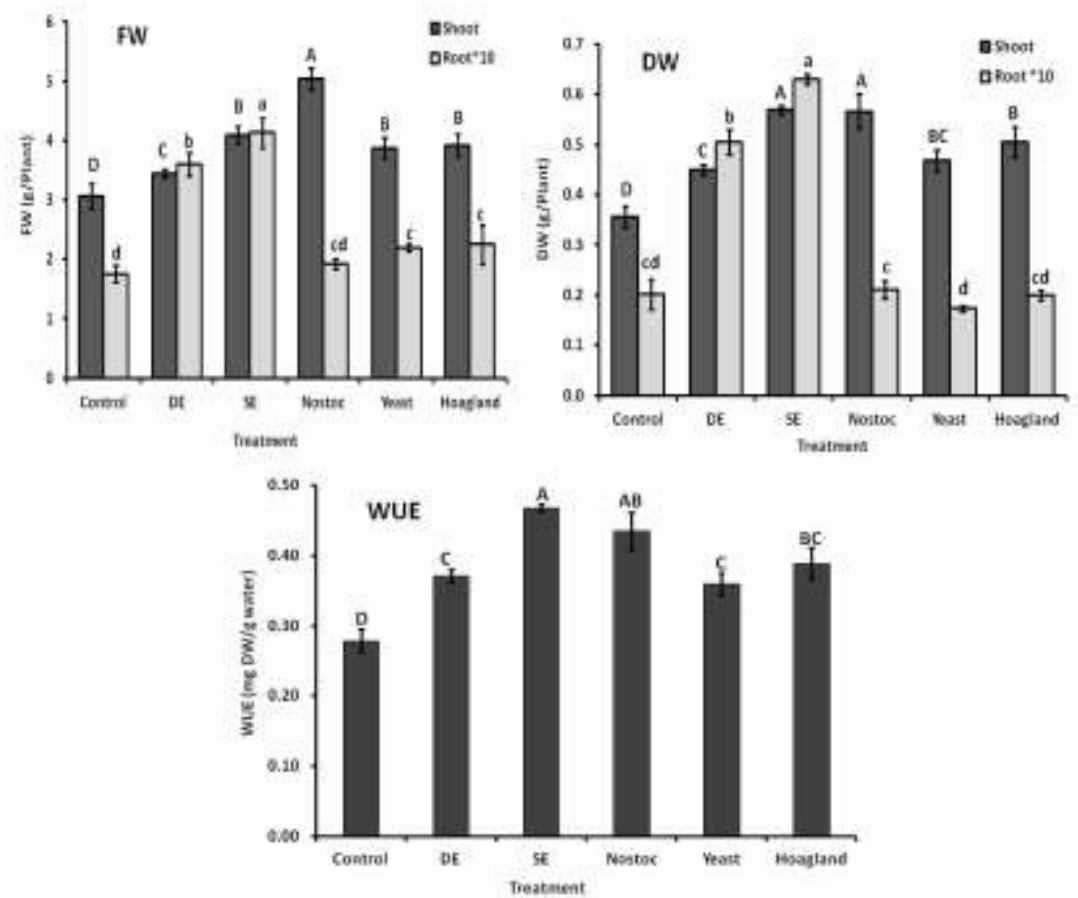

Fig. 1. Shoot and root fresh weight (FW), dry weight (DW), and Water use efficiency (WUE) of black seed (Nigella sativa) grown for three months on calcareous soil alone (control) or amended with biofertilizers $(6 \mathrm{~g} / 5 \mathrm{Kg}$ diatomaceous earth "DE", 20\% sewage effluent "SE", $1 \mathrm{mg} / \mathrm{L}$ Nostoc and $4 * 10^{12}$ cell/L yeast) in addition to $1 / 4 \times$ Hoagland solution. Each point is a mean of three replicates \pm SE. The letters (A-D) represent the statistical significance of each treatment on shoots at $p \leq 0.05$; a-d similarly represent those of roots.

Egypt. J. Bot. 57, No.1 (2017) 


\section{Plant Pigments}

The contents of photosynthetic pigments in Nigella sativa have been less enhanced by the studied treatments, compared with enhancements in plant biomass (Fig. 2). Chlorophylls a, b and carotenoids were significantly enhanced only in the Nostoc treated plants.

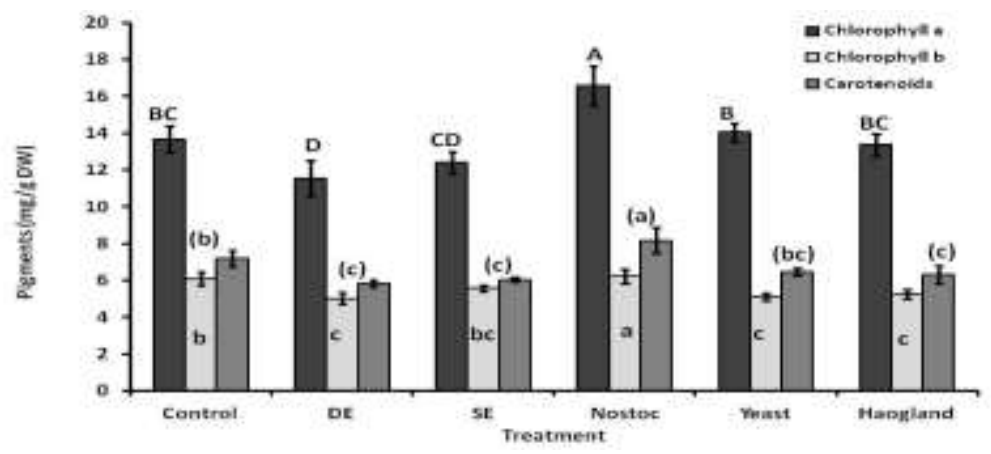

Fig. 2. Photosynthetic pigments (chlorophyll a, chlorophyll b and carotenoids) of black seed (Nigella sativa) grown for three months on calcareous soil alone (control) or amended with biofertilizers $(6 \mathrm{~g} / 5 \mathrm{Kg}$ diatomaceous earth "DE", $20 \%$ sewage effluent "SE", $1 \mathrm{mg} / \mathrm{L}$ Nostoc and $4 * 10^{12}$ cell/L yeast) in addition to 1/4x Hoagland solution. Each point is a mean of three replicates \pm SE. The letters (A-D) represent the statistical significance of each treatment on chlorophyll a at $P<0.05$; a-c similarly represent those of chlorophyll b, (a)-(c) similarly represent those of carotenoids.

\section{Carbohydrates}

Soluble carbohydrates were much higher in shoots than in roots (Fig. 3). The highest stimulation in shoot was induced by $20 \%$ sewage effluent and Nostoc treated plants reaching values of about $95 \%$ and $50 \%$ higher than control, respectively. The maximum carbohydrates induction in plant roots was about $130 \%$ higher than the control using both $20 \%$ sewage and $4 * 10^{12}$ cell/L yeast. However, 1/4x Hoagland medium relatively decreased shoots and root carbohydrate contents, compared to control.

\section{Proteins}

Soluble proteins exhibited an attitude opposite to that of carbohydrates. Soluble protein contents were much higher in roots than in shoots of Nigella sativa (Fig. 3). The increases showed highly significant values in the treated plants as follows: Hoagland $>$ yeast $>$ Nostoc.

\section{Amino acids}

Figure 3 displays amino acid concentration in shoots and roots of black seed plants. Shoot amino acids were much higher than those in roots, in a manner similar to that of soluble carbohydrates. The applied treatments significantly enhanced amino acid contents relative to respective controls (shoots or roots). 

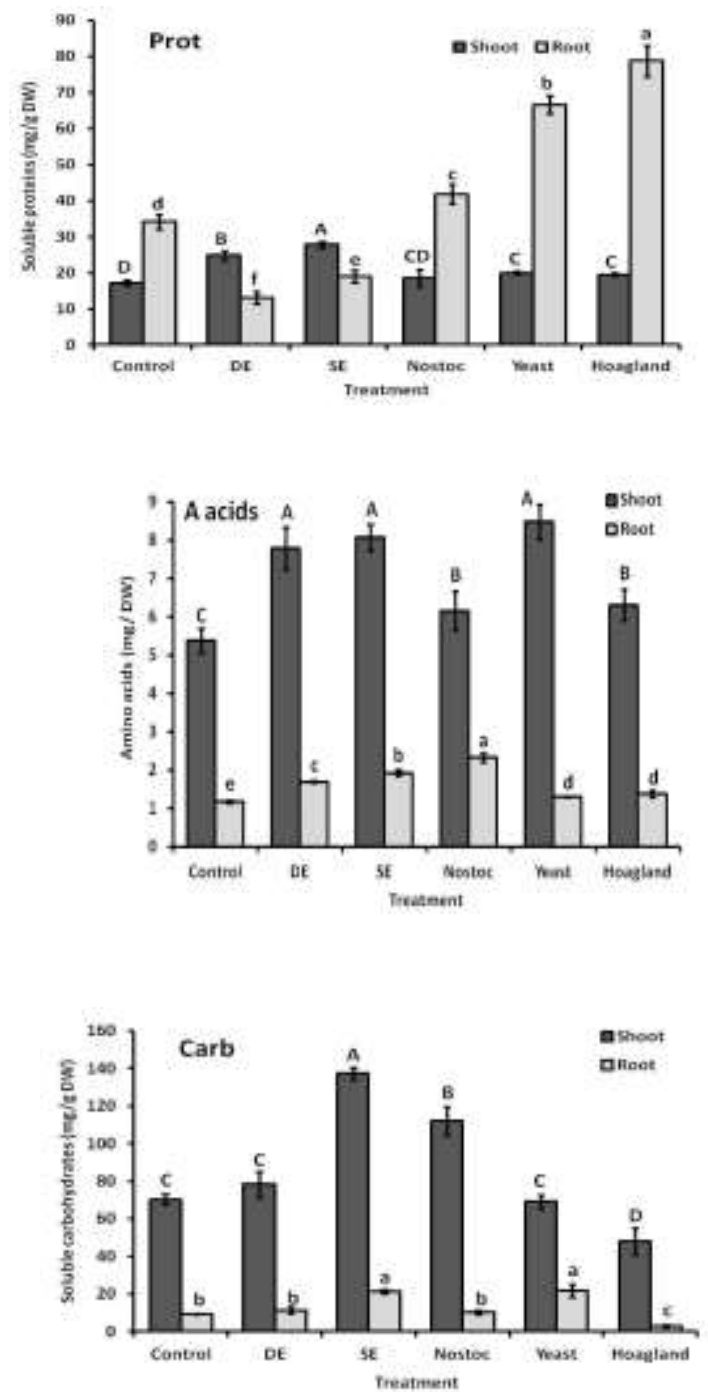

Fig. 3. Soluble carbohydrates (Carb), proteins (Prot) and amino acids (A acids) content (mg/g DW) of shoots and roots of black seed (Nigella sativa) grown for three months on calcareous soil alone (control) or amended with biofertilizers $(6 \mathrm{~g} / 5 \mathrm{Kg}$ diatomaceous earth "DE", $20 \%$ sewage effluent "SE", $1 \mathrm{mg} / \mathrm{L}$ Nostoc and $4 * 10^{12}$ cell/L yeast) in addition to $1 / 4 \times$ Hoagland solution. Each point is a mean of three replicates \pm SE. The letters (A-D) represent the statistical significance of each treatment on shoots at $P<0.05$; a-e similarly represent those of roots.

Egypt. J. Bot. 57, No.1 (2017) 
Proline

The effect of the studied treatments on proline accumulation in Negilla sativa leaves is presented in Fig. 4. All the studied treatments, under the selected concentrations, significantly decreased proline contents in leaves of the test plant, compared with the control (gown on calcareous soil only). The most pronounced proline inhibition has been detected in leaves of plants grown on $6 \mathrm{~g} / 5 \mathrm{Kg}$ diatoms-treated soil (72\% less than the control). One $\mathrm{mg} / \mathrm{L}$ Nostoc decreased proline content by about $55 \%$ than the control followed by $4 \mathrm{ml} / \mathrm{L}$ yeast extract (49\%) and $20 \%$ sewage (41\%). However, proline concentrations in leaves of Negilla sativa grown on 1/4x Hoagland treated soil were comparable to that of the control plants.

$M D A$

Malondialdehyde (MDA), an indicator of reactive oxygen species damage to cell membranes via lipids peroxidation, was assessed in plant roots (Fig. 4). The studied treatments, under all the selected concentrations, significantly inhibited MDA content, compared with the control plants. Six g/5 Kg diatomateous earth exerted the highest MDA inhibition (77\% less than control), which indicates the most stress recovery, compared with other treatments. Sewage $(20 \%), 4 * 10^{12}$ cell/L Yeast, $1 / 4 \mathrm{x}$ Hoagland medium and 1 $\mathrm{mg} / \mathrm{L}$ Nostoc decreased MDA concentration by about $56 \%, 43 \%, 16 \%$ and $15 \%$ lower than the control, respectively.
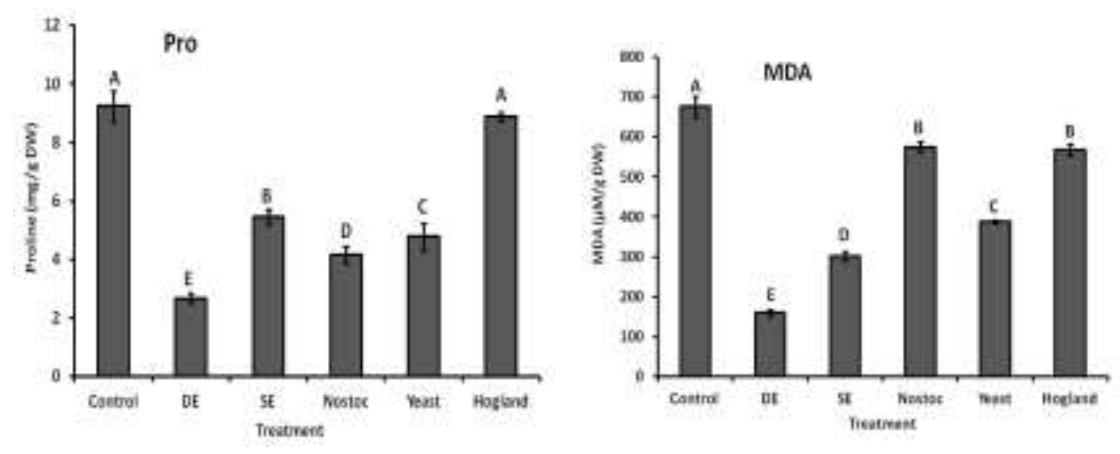

Fig. 4. Proline (Pro) contents (mg/g DW) of leaves and Malondialdehyde (MDA) contents $(\mu \mathrm{M} / \mathrm{g} \mathrm{DW})$ of roots of black seed (Nigella sativa) grown for three months on calcareous soil alone (control) or amended with biofertilizers (6 g/5 Kg diatomaceous earth "DE", 20\% sewage effluent "SE", $1 \mathrm{mg} / \mathrm{L}$ Nostoc and $4 * 10^{12}$ cell/L yeast) in addition to $1 / 4 \times$ Hoagland solution. Each point is a mean of three replicates \pm SE. Means marked with different letters indicate significant differences at $P<0.05$. 
Antioxidant enzymes

The antioxidant enzymes superoxide dismutase (SOD), catalase (CAT) and ascorbate peroxidase (APX) have been traced in leaves and roots of black seed plants grown at increasing concentrations of various biofertilizers.

\section{1-Superoxide dismutase (SOD)}

Figure 5 shows the inhibitory effect of certain concentrations of the studied treatments on SOD activity in plant shoots and roots. Sewage water (20\%) inhibited SOD activity in plant shoots by about $50 \%$ than the control while $6 \mathrm{~g} / 5 \mathrm{Kg}$ diatoms inhibited it by about $20 \%$, and $4 \mathrm{ml} / \mathrm{L}$ yeast inhibited it by $14 \%$ and $1 / 4$ Hoagland was only $10 \%$ lower than control. On the other hand, $1 \mathrm{mg} / \mathrm{L}$ Nostoc did not significantly change SOD activity in plant shoots, compared with the control.

Figure 5 also shows that $6 \mathrm{~g} / 5 \mathrm{Kg}$ diatoms and 20\% sewage inhibited SOD activity in plant roots by about $50 \%$ than the control, while $1 / 4 x$ Hoagland, $1 \mathrm{mg} / \mathrm{L}$ Nostoc and $4 * 10^{12}$ cell/L yeast inhibited SOD activity in plant root by about $46 \%, 43 \%$ and $17 \%$ than the control, respectively.

\section{2- Catalase (CAT)}

The results in Fig. 5 present the inhibition (lowest activity) of CAT in shoots of black seed plants exerted by certain levels of the applied biofertilizers. The most pronounced reduction in CAT activity was recorded by Hoagland $(1 / 4 \mathrm{x})$ reaching about $70 \%$ lower than the control. Diatoms $(6 \mathrm{~g} / 5$ $\mathrm{Kg}$ ), $20 \%$ sewage and $4 \mathrm{ml} / \mathrm{L}$ yeast inhibited CAT activity by about $35 \%$ than the control. Nostoc $(1 \mathrm{mg} / \mathrm{L})$ reduced CAT activity by only $10 \%$ of the control.

All the studied treatments also markedly inhibited CAT activity in Negilla sativa root under the selected concentrations. Nostoc $(1 \mathrm{mg} / \mathrm{L})$ and $20 \%$ sewage inhibited CAT activity by about $56 \%$ of the control. Also, $6 \mathrm{~g} / 5 \mathrm{Kg}$ diatoms, $1 / 4$ $\mathrm{X}$ Hoagland and $4 * 10^{12}$ cell/L yeast inhibited CAT activity by about $50 \%$, $34 \%$, and $10 \%$ than the control, respectively (Fig. 5).

\section{3- Ascorbate peroxidase (APX)}

The influence of the studied biofertilizers on APX activity in plant shoots is presented in Fig. 5. The selected concentrations of all the studied treatments variably inhibited APX activity as follows: $6 \mathrm{~g} / 5 \mathrm{Kg}$ diatoms, 1/4 X Hoagland, $1 \mathrm{mg} / \mathrm{L}$ Nostoc, $20 \%$ sewage and $4 * 10^{12}$ cell/L yeast inhibited APX activity by about $84 \%, 80 \%, 55 \%, 47 \%$, and $35 \%$ lower than the control, respectively.

In plant roots, most of studied treatments obviously inhibit APX activity. In this context, $6 \mathrm{~g} / 5 \mathrm{Kg}$ diatoms and $20 \%$ sewage inhibited APX activity by about $68 \%$ and $62 \%$ than the control (Fig. 5). While $1 \mathrm{mg} / \mathrm{L}$ Nostoc, 1/4x Hoagland and $4 \mathrm{ml} / \mathrm{L}$ yeast inhibited APX activity by about $45 \%, 24 \%$ and $10 \%$ than the control, respectively. 

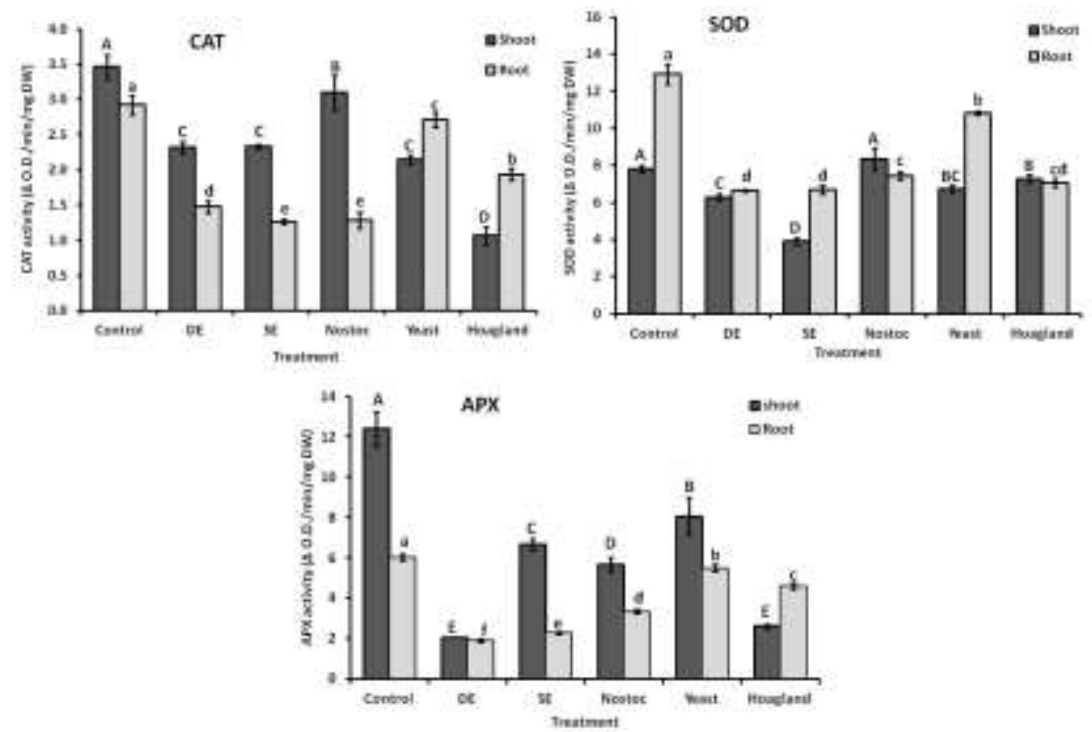

Fig. 5. Superoxide dismutase (SOD) activity ( $\Delta$ O.D. at $480 \mathrm{~nm} / \mathrm{min} / \mathrm{mg} \mathrm{DW}$ ), catalase (CAT) activity ( $\triangle$ O.D. at $240 \mathrm{~nm} / \mathrm{min} / \mathrm{mg}$ DW) and ascorbate peroxidase (APX) activity ( $\triangle$ O.D. at $290 \mathrm{~nm} / \mathrm{min} / \mathrm{mg} \mathrm{DW})$ of shoots and roots of black seed (Nigella sativa) grown for three months on calcareous soil alone (control) or amended with biofertilizers $(6 \mathrm{~g} / 5 \mathrm{Kg}$ diatomaceous earth "DE", $20 \%$ sewage effluent "SE", $1 \mathrm{mg} / \mathrm{L}$ Nostoc and $4 * 10$ " cell/L yeast) in addition to 1/4x Hoagland solution. Each point is a mean of three replicates \pm SE. The letters (A-D) represent the statistical significance of each treatment on shoots at $P<0.05$; a-e similarly represent those of roots.

\section{Discussion}

Several approaches are conventionally applied to improve the stressful characteristics of calcareous soils; among which biofertilizers application that has been adopted in this investigation. Although, all concentrations of all the studied biofertilizers applied were stimulatory to plant growth, only the most efficient concentration of each treatment, in enhancing the plant fresh weight and dry mass, is presented in this work. The water use efficiency has been also significantly improved; one of the factors to which enhanced plant growth could be ascribed.

The four applied biofertilizers affected the plant growth and metabolism in different ways that are briefly described in this context. Diatoms are the world's largest contributors to bio-silicification and are one of the predominant contributors to global carbon fixation (Veronique et al., 2000). The element silicon ( $\mathrm{Si}$ ) is absorbed from soil in large amounts that are several folds higher than other essential macronutrients in certain plant species (Datnoff et al., 1998). Si is not considered by many plant scientists as an essential nutrient for plant function (Epstein, 1994). However, its beneficial effects have been 
reported in various situations, especially under biotic and abiotic stress conditions. The most significant effect of Si to plants, besides improving their fitness in nature and increasing agricultural productivity, is the restriction of parasitism (Rodrigues et al., 2003).

Yeast has been applied as a biofertilizer to improve the characteristics of calcareous soil. Yeast helps in supplying plants with vitamins (B complex) and growth regulating hormones (IAA, Gibberellins, Cytokinins) which increase leaf area, photosynthetic pigments (Chlorophylls a, b), vegetative growth and flowering (Amer, 2004). In addition, yeast produces organic acids and chelating agents, which increase mineral nutrient uptake ( $\mathrm{P}, \mathrm{Fe}, \mathrm{Zn}, \mathrm{Mn}$ ) (Mostafa and El-Hosseiny, 2001). Yeast can also act as a biocontrol agent against certain plant diseases (El-Tarabily and Sivasithamparam, 2006).

In addition, cyanobacteria attracted the attention of scientists as biofertilizers due to their nitrogen fixing capacity, and hence their role in the maintenance of soil fertility is well documented (Abdel-Aziez et al., 2014). Cyanobacteria that dominate a wide range of diverse environments are characterized by their tolerance to high temperatures, desiccation, $\mathrm{pH}$, salinity, light intensity and nutrients (Whitton, 2000), where survival of which under such harsh conditions sustains prolonged soil amendment. Nitrogen fixed by the symbiotic association of cyanobacteria (cyanobionts) is transferred to and used by various plant groups (Kannaiyan et al., 1997).

In the soil amended with sludges, the total $\mathrm{N}$ and extractable $\mathrm{N}$ and $\mathrm{P}$ contents increased (Bourioug et al., 2015). Roig et al. (2012) showed that sludge amendments increased the organic matter content (and its aromaticity), enhanced microbial activity and improved carbon and nitrogen mineralization processes and some enzymatic functions. Through sludge application, the levels of $\mathrm{Cu}, \mathrm{Zn}$, and $\mathrm{Pb}$ increased, the $\mathrm{Fe}$ content decreased while the extractability of $\mathrm{Fe}, \mathrm{Cu}, \mathrm{Mn}, \mathrm{Zn}$, and $\mathrm{Pb}$ increased as compared to the control (Hernández et al., 2014). El-Zohri et al. (2014) reviewed the use of sewage in agriculture and some related processes.

The applied treatments significantly, although variably, enhanced carbohydrates, proteins and amino acid contents of plant shoots and roots. Soluble carbohydrates were much higher in shoots of Nigella sativa than in roots whereas soluble proteins exhibited an attitude opposite to that of carbohydrates, i.e. were higher in roots. Shot amino acids were much higher than those in roots, in a manner similar to that of soluble carbohydrates, i.e. the shoot body was highly composed of carbohydrates and amino acid proportions while soluble proteins were dominant in the root. These metabolic shifts might be due to nitrogen availability and/or hydrolytic activity. Nitrogen limitation might have resulted in high soluble carbohydrates in shoots while high amino acids/ proteins ratios could be ascribed to an enhanced hydrolytic activity, triggered by the applied treatments.

Egypt. J. Bot. 57, No.1 (2017) 
The most noticeably pronounced and common mode of action of the applied treatments is their significant inhibition of the stress markers and antioxidant enzymes; that, in turn, exerted a positive impact on growth. Plants developed defense strategies against the toxicity of the reactive oxygen species (ROS), involving both limiting the formation of ROS as well as metabolizing them. Many enzymes and molecules are involved in protecting cells from the adverse effects of oxidative stress. Antioxidant activity of molecules such as phenols is mainly attributed to their redox actions, neutralizing free radicals, quenching singlet and triplet oxygen, or decomposing peroxides (Osawa, 1994). ROS such as hydrogen peroxide, superoxide radicals are produced in both stressed and unstressed cells. ROS can start a chain reaction and cause damage to the cellular systems. Regardless of being toxic species, which may have adverse effects on cells growth and metabolism, ROS and free radicals are essential for normal cellular functioning since they act as signaling molecules (Foyer and Noctor, 2009).

The activity of some antioxidant enzymes in addition to some stress markers in Negilla sativa, as influenced by the various treatments, was also followed in the current study. The activity of all of these enzymes (superoxide dismutase, catalase and ascorbate peroxidase) have been significantly inhibited at the selected concentrations of all the applied treatments. As well, levels of proline and malondialdehyde (MDA) as conventional stress markers exhibited their lowest values at the stated concentrations. Superoxide dismutase constitutes the first line of defense against ROS as it converts superoxide free radical anion $\left(\mathrm{O}_{2}{ }^{\circ}\right)$ to $\mathrm{H}_{2} \mathrm{O}_{2}$ and $\mathrm{O}_{2}$ (Rahnama and Ebrahimzadeh, 2005). Then, catalase and ascorbate peroxidase detoxify hydrogen peroxide in the peroxisomes, cytosol and chloroplast. None of the applied treatments induced enhancement in antioxidant enzymes activity of black seed plants (shoots and roots), compared with the control, indicating no oxidative stress is exerted as a result of applying these treatments. Proline accumulation, a common stress marker in variously stressed plants, was also decreased by the applied treatments, that might indicate stress relief. Malondialdehyde (MDA), indicative for membrane lipid peroxidation and functional damage, has been also significantly inhibited by the applied treatments. These were assumed to imply that the characteristic stress of calcareous soil has been relieved by the applied treatments.

Although Hoagland nutrient medium does not contain any organic matter, it was of significant stimulatory effect on plants growth and was accompanied with significantly inhibited stress markers and antioxidant enzymes. This would be attributed to its action as a mineral element supplement to compensate for mineral unavailability in calcareous soil, not least due to high $\mathrm{pH}$ and calcification.

Concomitance of thehighest biomass of plant shoots and roots with lowest activity of antioxidant enzymes (SOD, CAT and APX) and the lowest levels of stress markers (proline and MDA) indicated a strong correlation between 
stimulated growth and inhibited antioxidant system. We hypothesized that the energy leakage into synthesizing and accumulating stress markers and antioxidant systems has been saved by the defined concentrations of the applied biofertilizers, consequently, energy and carbon skeletons would have been diverted to growth (dry mass accumulation).

\section{Conclusion}

Calcareous soil may be reclaimed by any of the biofertilizer treatments applied in the present work. The test plant Nigella sativa is a relevant crop to be cultivated in such soil and can significantly benefit from the amendments applied. Continuous cultivation will increase the organic matter content in soil by the cumulative effect that improves the edaphic factors for agriculture. A major mode of action triggered by the studied biofertilizers is the significant inhibition of the tested stress markers (proline and MDA) and antioxidant enzymes (SOD, CAT and APX); inhibition of both of them was assumed to save energy and carbon skeletons that would be reflected as the recorded enhancement of plant growth (dry mass accumulation).

\section{References}

Abdel-Aziez, S.M., Eweda, W.E., Girgis, M.G.Z. and Abdel Ghany, B.F. (2014) Improving the productivity and quality of black cumin (Nigella sativa) by using Azotobacter as $\mathrm{N}_{2}$ biofertilizer. Annals of Agricultural Sciences, 59(1), 95-108.

Abu-Elela, E.G.Y. (2002) The Dynamic Changes in Chemical and Mineralogical Characteristics of Calcids Soils as Affected by Natural Soil Amendments. Ph.D. Thesis, Fac Agric, Ain Shams Univ, Cairo, Egypt.

Aebi, H. (1984) Catalase In: 1 (Ed) “Methods in Enzymology” Paker 1 (Ed) Academic press, Orlando, Fl, USA, 105: 121-126.

Al-Gaby, A.M.A. (1998) Amino acid composition and biological effects of supplementing broad bean and corn proteins with Nigella sativa (black cumin) cake protein. Nahrung., 42: 290-294.

Al-Naggar, T.B., Gómez-Serranillos, M.P., Carretero, M.E. and Villar, A.M. (2003) Neuropharmacological activity of Nigella sativa L. extracts. $J$. Ethnopharmacol., 88: 63-68.

Amer, S.S.A. (2004) Growth, green pods yield and seeds yield of common bean (Phaseolus vulgaris L.) as affected by active dry yeast, salicylic acid and their interaction. J. Agric. Sci. Mansoura. Univ., 29(3): 1407-1422.

Bates, S., Waldren, R.P. and Teare, I.D. (1973) Rapid determination of free proline for water-stress studies. Plant Soil, 39: 205-207.

Bourioug, M., Alaoui-Sehmer, L., Laffray, X., Benbrahim, M., Aleya, L. and Alaoui-Sossé, B. (2015) Sewage sludge fertilization in larch seedlings: Effects on trace metal accumulation and growth performance. Ecol. Eng., 77: 216-224.

Egypt. J. Bot. 57, No.1 (2017) 
Brody, N.C. and Weil, R.R. (1999) "The Nature and Properties of Soils". $12^{\text {th }}$ ed. Prentice Hall, Upper Saddle River, New Jersey. pp. 992.

Burits, M. and Bucar, F. (2000) Antioxidant activity of Nigella sativa essential oil. Phytother. Res., 14: 323-328.

Datnoff, L.E., Victoria-Correa, F.J., Seebold, K.W. and Snyder, G.H. (1998) Selicon management of blast in upland and irrigated rice ecosystems, In: Tharreau D, Lebrun MH, Nicholas Talbot, J.L. Notteghem (Eds), Advances in Rice Blast Research: Proceedings of the $2^{\text {nd }}$ International Rice Blast Conference 4-8 August 1998, Montpellier, France. Kluwer publishers, pp. 180-187.

Elgabaly, M.M., Gewaifel, I.M., Hassan, M.N. and Rozanov, B.G. (1969) Soil Map and Land Resources of the United Arab Republic. Institute of Land Reclamation, Alexandria University, Egypt. Res. Bull., No. 22.

El-Tarabily, E.A. and Sivasithamparam, K. (2006) Potential of yeasts as biocontrol agents of soil-borne fungal plant pathogens and as plant growth promoters. Mycoscience, 47(1): 25-35.

El-Zohri, M., Hifney, A.F., Ramadan, T. and Abdel-Basset, R. (2014) The Use of Sewage in Agriculture and Related Activities in: "Handbook of Plant and Crop Physiology" Pessarakli, M. (Ed) ( ${ }^{\text {rd }}$ ed.) Taylor\& Francis, New York, USA, pp. 931-958.

Epstein, E. (1994) The anomaly of silicon in plant biology. Proc. Natl. Acad. Sci. USA, 91: 11-17.

FAO (2014) Management of calcareous soils. In: http://www.fao.org/soils-portal/soilmanagement/management-of-some-problem-soils/calcareous-soils/en/\#c239674.

Foyer, C. and Noctor, G. (2009) Redox regulation in photosynthetic organisms: signaling, acclimation, and practical implications. Antioxid. Redox Signal., 11: 861905 .

Gilani, A.H., Jabeen, Q. and Khan, M.A.U. (2004) A review of medicinal uses of pharmacological activities of Nigella sativa. Pak. J. Biol. Sci., 7(4): 441-451.

Heath, R.L. and Packer, L. (1968) Photoperoxidation in isolated chloroplasts. I. Kinetics and stochiometry of fatty acid peroxidation. Arch. Biochem. Biophys., 125: 189-198.

Hernández, T., Moreno, J.I. and Costa, F. (2014) Influence of sewage sludge application on crop yields and heavy metal availability. Soil Sci. Plant Nutr., 37(2): 201-210.

Hoagland, D.R. and Arnon, D.I. (1950) The water-culture method for growing plants without soil. Cal. Agric. Exp. Sta. Cir., 347: 1-32.

Kadry, L.T. (1973) Distribution of calcareous soils in the Near East region, their reclamation and land use measures and achievements. In: "FAO Soils Bulletin 21 - 
Calcareous Soils, Food and Agriculture Organization of the United Nations", Rome, pp. 17-27.

Kannaiyan, S., Aruna, S.J., Kumari, S.M.P. and Hall, D.O. (1997) Immobilized cyanobacteria as a biofertilizer for rice crops. J. Appl. Phycol., 9: 167-174.

Lichtenthaler, H.K. (1987) Chlorophylls and Carotenoids: Pigments of Photosynthetic Biomembranes. In: "Methods in Enzymology" Academic press, Orlando, Fl., USA, 148, 350-183.

Loeppert, R.H. and Suarez, D.L (1996) Carbonate and gypsum, In: D.L., Sparks Page, A.L., P.A., Helmke, R.H., Loeppert, P.N., Soltanpour, M.A., Tabatabai, Johnson, C.T., Sumner M.E. (Eds). "Methods of Soil Analysis Part 3 Chemical Methods". SSSA Special Publication No. 5. Madison, WI, pp. 437-474.

Lowry, O.H., Rosebrough, N.J., Farr, A.L. and Randall, R.J. (1951) Protein measurement with Folin phenol reagent. J. Biol. Chem., 193: 265-275.

Marschner, H. (1995) “Mineral Nutrition of Higher Plants". $2^{\text {nd }}$ Edition. Academic Press, London.

Misra, H.P. and Fridovich, I. (1972) The role of superoxide anion in the autoxidation of epinephrine and a simple assay for superoxide dismutase. J. Biol. Chem., 247: 3170-3175.

Moore, S. and Stein, W.W. (1948) Amino acid free photometric ninhydrin method for use in chromatography of amino acids. J. Biol. Chem., 176: 367-388.

Mostafa, M.F. and El-Hosseiny, A.A. (2001) Effect of soil application of active dry yeast on growth, yield and fruit quality of Grand nain banana cv. Arab Univ J. Agric Sci, Ain Shams University, Cairo., 12(2): 693-704.

Nakano, Y. and Asada, K. (1981) Hydrogen peroxide is scavenged by ascorbate specific peroxidase in spinach chloroplanst. Plant Cell Physiol., 22: 867-880.

Osawa, T. (1994) Novel natural antioxidants for utilization in food and biological systems. In: Uritani L, Garcia VV, Mendoza EM (Eds) "Post Harvest Biochemistry of Plant Food Materials in Tropics". Japan Scientific Societies Press, Tokyo, Japan, pp. 241-251.

Pereira, S.I.A. and Castro, P.M.L. (2014) Phosphate-solubilizing rhizobacteria enhance Zea mays growth in agricultural P-deficient soils. Ecol. Eng., 73: 526-535.

Rahnama, H. and Ebrahimzadeh, H. (2005) The effect of $\mathrm{NaCl}$ on antioxidant enzyme activity in potato seedlings. Biol. Plant., 49: 93-97.

Rodrigues, F.Á., Benhamou, N., Datnoff, L.E., Jones, J.B. and Bélanger, R.R. (2003) Ultrastructural and cytochemical aspects of silicon-mediated rice blast resistance. Phytopathology. 93: 535-546. 
Roig, N., Sierra, J., Martí, E., Nadal, M., Schuhmacher, M. and Domingo, J.L. (2012) Long-term amendment of Spanish soils with sewage sludge: Effects on soil functioning. Agric. Ecosyst. Environ., 158: 41-48.

Schlegel, H.G. (1956) Die Verwertung organischer sauren duch Chlorella in licht. Planta, 47: 510-526.

Subhash, P., Sanjeev, B., Aami, A., Ramzi, M. and Fazlul, H.S. (2008) From here to eternity the secret of Pharaohs: therapeutic potential of black cumin seeds and beyond. Cancer Ther., 6: 495-510.

Veronique, M.J., Mark, H. and Mark, A.B. (2000) Silicon metabolism in Diatoms: Implications for growth. J. Phycol., 36: 821-840.

Whitton, B.A. (2000) Soils and rice-fields. In: Whitton BA, Potts M (eds) The ecology of cyanobacteria: Their diversity in time and space. Kluwer Academic Pubs., Netherlands, pp. 233-255. 


\section{بعض المخصبات الحيوية تزيل أثار الإجهاد للتربة الرملية

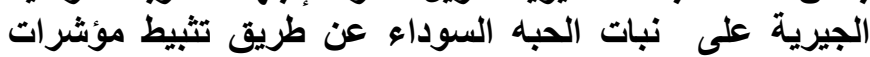 الإجهاد و الإتزيمات المضادة للأكسدة مع تحفيز نمو النبات

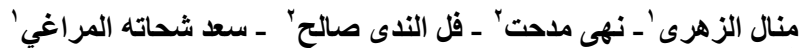

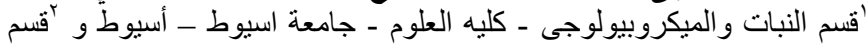

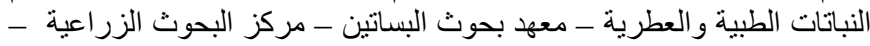

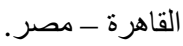

التربة الرملية الجيرية لها خصائص مجهدة لنمو النبات و هي تمثل حوالي إهب-

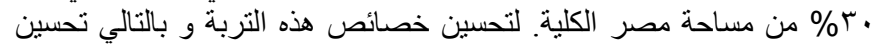

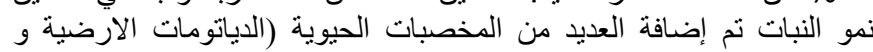

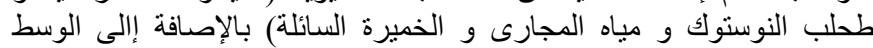

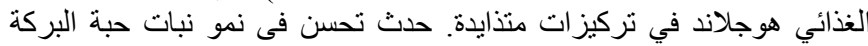

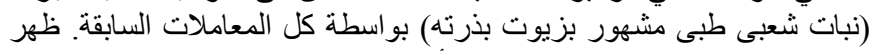

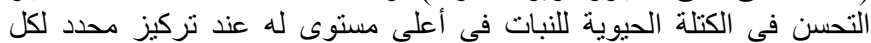

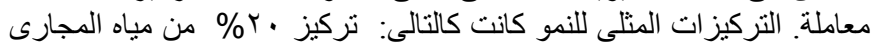

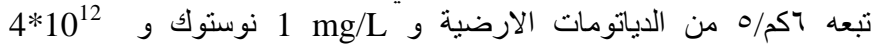

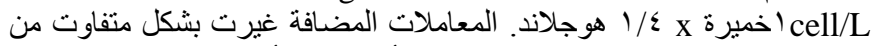

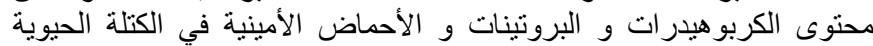

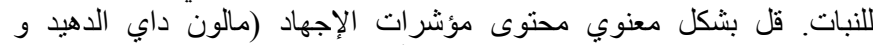

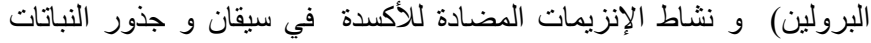

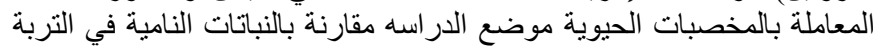

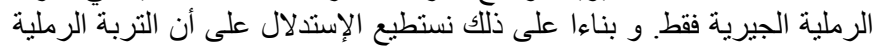

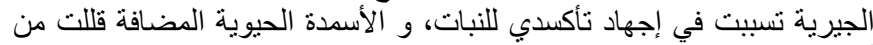

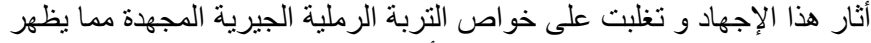

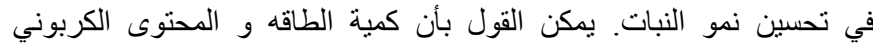

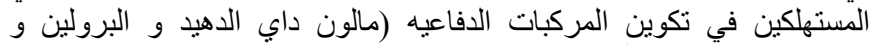
الإنزيمات المضادة للأكسدة تم توفير ها لنمو النبات النيات عند معالجة التربة الرملية البرولية 